\title{
Analisis Preferensi dan Kepuasan Konsumen terhadap Beras di Kecamatan Mulyorejo Surabaya Jawa Timur (The Analysis of Preferences and Customer Satisfaction on Rice in Mulyorejo District, Surabaya, East Java)
}

\author{
Rita Nurmalina, dan Endang Pudji Astuti \\ Departemen Agribisnis, Fakultas Ekonomi Manajemen Institut Pertanian Bogor \\ rita_ns@yahoo.com
}

Diterima 15 Januari 2011/Disetujui 9 Februari 2011

\begin{abstract}
Rice is a very important commodity. Rice plays an important role in food security, economic stability, and employment. Consumer behavior in rice consumption continues to grow. Improved incomes lead to increased demands on quality. Changes in demographic structures, such as level of education, lifestyle, technology, transportation, and communication, affect the customer preferences and satisfaction with the rice they consume. In line with efforts to increase productivity, the rice should be produced to meet consumer expectations which are constantly evolving. This study aimed to identify the characteristics, analyze the decision-making process, preferences, and customer satisfaction, as well as making the right marketing mix recommendations based on the study of consumer behavior on three different social classes (lower class, middle, and upper). Convinience Sampling was used. The analytical tool used in this study was a descriptive analysis, Important \& Performance Analysis (IPA) and the Customer Satisfaction Index (CSI). Data processing with descriptive analysis showed some differences in the characteristics of responders and decision-making processes at all three social classes. The differences associated with educational level and family income levels, initial consideration of the purchase of rice, and where to purchase the rice. CSI showed that the total satisfaction on all three social classes is entirely in the range "satisfied". However, the higher the social class, the higher the satisfaction of the rice consumed. Data processing by IPA showed that the performance, which should be improved based on consumer preference and satisfaction, was a top-class ease of getting rice and seller services. The performance on middle-class consumers have to be improved in assessing durability of rice, grain uniformity, and broken. While the upscale consumer should improve performance in terms of price, flavor, broken, and clean rice.

Keywords: consumption, quality, expectation, social class, sample, performance.
\end{abstract}

\section{Latar Belakang}

\section{PENDAHULUAN}

Beras adalah komoditas pangan pokok yang dikonsumsi oleh sebagian besar penduduk Indonesia sehingga masalah konsumsi beras dan pemenuhannya akan tetap menjadi hal penting dalam pembangunan ekonomi Indonesia. Beras juga sangat penting terkait jumlah produsen dan konsumennya di Indonesia. Dari sisi produsen, usahatani padi di Indonesia melibatkan 25,4 juta rumah tangga. Sedangkan dari sisi konsumen, lebih dari 90 persen penduduk Indonesia mengkonsumsi beras sebagai makanan pokok, dan sekitar 30 persen dari total pengeluaran rumah tangga miskin dipergunakan untuk membeli beras (Bustaman, 2003). Ini menunjukkan posisi beras yang sangat strategis sebagai penopang ketahanan pangan di Indonesia. 
Sebagian besar beras dikonsumsi setelah diolah menjadi nasi. Memakan nasi terkait erat dengan budaya makan dan citra status sosial di masyarakat. Surono (1998) dalam Selamet (2003) menyatakan bahwa pola konsumsi beras masyarakat Indonesia tidak dapat dirubah secara drastis karena berkaitan dengan budaya masyarakat yang sudah demikian melekat.

Konsumsi beras perkapita yang tinggi, disertai peningkatan jumlah penduduk Indonesia yang sebagian besar mengkonsumsi beras menyebabkan total konsumsi beras nasional yang tinggi setiap tahunnya. Pemenuhan kebutuhan beras tersebut dapat diusahakan dengan memproduksi sendiri dan mengimpor dari luar negeri. Bagi negara dengan kebutuhan beras yang besar seperti Indonesia, bergantung pada pasar impor jelas berisiko. Mengingat pentingnya beras bagi masyarakat Indonesia, sejalan dengan adanya upaya peningkatan produktivitas, beras yang dihasilkan seharusnya dapat memenuhi kebutuhan dan keinginan konsumen yang terus berkembang seiring berjalannya waktu.

Beras dikonsumsi oleh masyarakat baik individu, rumah tangga, maupun usaha jasa. Konsumen beras pun terdiri dari beragam kelas sosial, baik ditinjau dari pekerjaan, pendapatan, kekayaan, dan variabel kelas sosial lainnya. Garis pendapatan-konsumsi menunjukkan bahwa perbedaan pendapatan yang diperoleh menyebabkan perbedaan pola konsumsi pada setiap konsumen. Perbedaan pendapatan merupakan salah satu indikator perbedaan kelas sosial (Lipsey dkk, 1995). Hal ini menyebabkan perbedaan perilaku konsumen dalam mengkonsumsi beras pada kelas sosial yang berbeda.

Kemajuan di berbagai bidang telah mempengaruhi pola permintaan pangan, termasuk permintaan beras sebagai salah satu makanan pokok. Peningkatan pendapatan masyarakat mengakibatkan peningkatan tuntutan terhadap mutu. Di sisi lain, perubahan demografi seperti tingkat pendidikan, tingkat urbanisasi, dan tingkat partisipasi angkatan kerja wanita disertai kemajuan transportasi dan komunikasi saat ini, mempengaruhi preferensi konsumen. Konsumen lebih menekankan pada keseimbangan mutu, gizi, dan estetika. Sedangkan meningkatnya partisipasi angkatan kerja wanita, khususnya daerah perkotaan mendorong konsumen memilih bahan pangan yang dikemas sedemikian rupa sehingga mereka merasa nyaman dalam berbelanja, mudah dimasak, dan mudah menyiapkannya.

Selama ini pemerintah berusaha meningkatkan kuantitas dan produktivitas beras untuk mencukupi kebutuhan. Namun selain peningkatan kuantitas, preferensi dan kepuasan yang terus berkembang menuntut adanya peningkatan pada kualitas beras yang selama ini dikonsumsi (Jufri, 2006). Peningkatan pendapatan masyarakat mengakibatkan peningkatan tuntutan terhadap mutu. Untuk menghasilkan beras yang sesuai dengan harapan konsumen, langkah awal yang harus diperhatikan produsen adalah pengetahuan mengenai perilaku konsumen. Hal ini perlu dilakukan agar setiap keputusan yang diambil dapat meningkatkan kepuasan konsumen terhadap beras yang dikonsumsinya.

\section{Tujuan Penelitian}

Tujuan dari penulisan ini yaitu : (1) mengkaji karakteristik konsumen beras, (2) menganalisis proses pengambilan keputusan yang dilakukan konsumen dalam pembelian beras, (3) menganalisis preferensi konsumen terhadap beras dikaitkan dengan atribut-atribut beras, (4) menganalisis kepuasan konsumen terhadap beras dikaitkan dengan atribut-atribut beras. 


\section{Lokasi dan Waktu penelitian}

\section{METODOLOGI}

Penelitian ini dilakukan di Kecamatan Mulyorejo Surabaya Jawa Timur. Penentuan lokasi ini dilakukan secara sengaja (purposive) dengan mempertimbangkan bahwa Provinsi Jawa Timur merupakan salah satu sentra produksi padi di Indonesia, dan kelurahan Mulyorejo mempunyai latar belakang status sosial yang beragam. Penelitian dilakukan pada Februari - Maret 2007.

\section{Jenis dan Sumber Data}

Jenis data yang digunakan adalah data primer dan sekunder. Data primer diperoleh dengan menyebarkan kuesioner (pertanyaan tertutup dan terbuka). Data sekunder diperoleh dari studi di Perpustakaan LSI IPB, Perpustakaan Sosial Ekonomi Pertanian, Pusat Studi Sosial Ekonomi, Departemen Pertanian, Badan Pusat Statistik, buku, internet, dan literatur-literatur lainnya yang terkait dengan topik penelitian.

Metode penarikan sampel yang digunakan dalam penelitian ini adalah non probability sampling, yaitu dengan metode convinience sampling, yaitu metode yang memberikan kebebasan pada peneliti dalam memilih responden di lokasi penelitian berdasarkan kemudahan penelitian (Nazir, 1985). Peneliti sengaja mengelompokkan konsumen yang diteliti berdasarkan kelas sosial yaitu kelas atas, menengah, dan bawah. Lapisan sampel dibuat berdasarkan kriteria tahapan keluarga sejahtera yang dikeluarkan Badan Koordinasi Keluarga Berencana Nasional (BKKBN). Penentuan jumlah sampel ditentukan dengan metode Slovin dalam Umar (2002) berjumlah 100 responden, 33 orang responden kelas bawah, 33 orang responden kelas menengah, dan 34 orang responden kelas atas.

\section{Metode Analisis Data Analisis Deskriptif}

Analisis deskriptif adalah analisis yang menghasilkan output data sampai pada taraf deskriptif, yaitu menganalisis dan menyajikan fakta secara sistematik sehingga dapat lebih mudah dipahami dan disimpulkan (Winartha, 2006). Menurut Travers (1978), analisis deskriptif bertujuan menggambarkan sifat sesuatu yang sedang berlangsung pada saat riset dilakukan dan memeriksa sebab-sebab dari sesuatu gejala tersebut. Analisis ini berguna untuk menjawab perumusan masalah terkait proses keputusan pembelian.

\section{Customer Satisfaction Index (CSI)}

Customer Satisfaction Index digunakan untuk menentukan tingkat kepuasan pelanggan secara menyeluruh dengan pendekatan yang mempertimbangkan tingkat kepentingan dari atribut-atribut kualitas jasa yang diukur. Metode pengukuran CSI ini meliputi tahap-tahap sebagai berikut (Stratford, 2007) :

(1). Menghitung weighting factors (WF) dari nilai rata-rata tingkat kepentingan atau mean important score (MIS). Bobot ini merupakan persentase nilai MIS per atribut terhadap total MIS seluruh atribut. i adalah atribut ke-l.

$$
\mathrm{WF}=\frac{\mathrm{MISi}}{\text { TotalMIS }} \times 100 \%
$$

(2). Menghitung weigted score (WS), yaitu bobot perkalian antara WF dengan rata-rata tingkat kinerja atau mean satisfaction score (MSS).

$$
\text { WS }=\text { MSS } \times \text { WF }
$$

(3). Menghitung weighted average total (WAT), yaitu menjumlahkan weigted score dari semua atribut. Dalam penelitian ini, atribut berjumlah 19.

$$
\mathrm{WAT}=\mathrm{WS}_{1}+\mathrm{WS}_{2}+\ldots .+\mathrm{WS}_{19}
$$


(4). Menghitung customer satisfaction index (CSI), yaitu weighted average total (WAT) dibagi highest scale (HS).

$$
\mathrm{CSI}=\frac{\mathrm{WAT}}{\mathrm{HS}} \times 100 \%
$$

Berdasarkan Simamora (2005), untuk membuat skala linier numerik, pertama-tama kita cari rentang skala $(\mathrm{RS})$ :

$$
\mathrm{RS}=\frac{m-n}{b}
$$

Dimana: $\quad m=$ Skor tertinggi

$\mathrm{n}=$ Skor terendah

$\mathrm{b}=$ Jumlah kelas atau kategori yang akan dibuat

Untuk penelitian ini, rentang skalanya adalah : $R S=[(100-0) / 5] \times 100 \%=20 \%$

Berdasarkan rentang skala di atas, maka kriteria kepuasannya adalah sebagai berikut :

$0 \%-20 \%$

$20 \%<$ satisfaction index $\leq 40 \%$

$=\quad$ sangat tidak puas

$40 \%<$ satisfaction index $\leq 60 \%$

$=\quad$ tidak puas

$60 \%<$ satisfaction index $\leq 80 \% \quad=$ puas

$80 \%<$ satisfaction index $\leq 1.00 \% \quad=\quad$ sangat puas

\section{Important and Performance Analysis}

Important and Performance Analysis adalah suatu teknik penerapan yang mudah untuk mengukur tingkat kepentingan dan tingkat kinerja untuk pengembangan program pemasaran yang efektif. Analisis ini bertujuan menjawab perumusan masalah terkait preferensi konsumen terhadap atribut beras dilihat dari tingkat kepentingan responden terhadap atribut.

Langkah pertama yaitu menentukan skor dari setiap indikator variabel $X$ dan $Y$ dengan mengalikan seluruh frekuensi data dengan bobotnya. Bobot untuk tingkat kepentingan dan kinerja menggunakan tingkat skala Likert dimana sangat baik/sangat penting diberi bobot 5 , baik/penting bobot 4 , biasa bobot 3 , kurang baik/kurang penting bobot 2, dan tidak baik/tidak penting diberi bobot 1 .

Langkah kedua membagi jumlah skor dengan banyaknya responden, hasilnya berupa skor rata-rata tingkat kepentingan dan skor rata-rata tingkat kinerja. Setiap atribut dapat dirumuskan sebagai berikut :

$$
\overline{\mathrm{X}}=\frac{\sum \mathrm{Xi}}{\mathrm{n}} \quad \text { dan } \overline{\mathrm{Y}}=\frac{\sum \mathrm{Yi}}{\mathrm{n}}
$$

Dengan : $\bar{X}=$ Bobot rata-rata tingkat penilaian kinerja atribut produk

$\overline{\mathrm{Y}}=$ Bobot rata-rata penilaian kepentingan pelanggan

$\mathrm{n}=$ Jumlah responden

$\Sigma \mathrm{Xi}=$ Total skor tingkat kinerja setiap responden

$\Sigma \mathrm{Yi}=$ Total skor tingkat kinerja setiap responden

Selanjutnya skor rata-rata tingkat kepentingan dan kinerja pada diagram kartesius Important\&Performance Analysis yang dapat dilihat pada gambar 1. Diagram kartesius tersebut adalah suatu bangun yang dibagi menjadi empat bagian yang dibatasi oleh dua buah garis yang berpotongan tegak lurus pada suatu titik $(\mathrm{X}, \overline{\mathrm{Y}})$. Rumusnya : 


$$
=\frac{\sum_{\mathrm{i}=1}^{\mathrm{n}} \overline{\mathrm{Xi}}}{\mathrm{K}} \quad \operatorname{dan} \mathrm{Y}=\frac{\sum_{\mathrm{i}=1}^{\mathrm{n}} \overline{\mathrm{Yi}}}{\mathrm{K}}
$$

Dimana $: \quad \stackrel{\bar{X}}{=}=$ Rata-rata dari rata-rata bobot tingkat kinerja responden atribut produk

$\overline{\mathrm{Y}}=$ Rata-rata dari rata-rata tingkat kepentingan responden atribut produk

$\mathrm{K}=$ Banyaknya atribut dalam penelitian

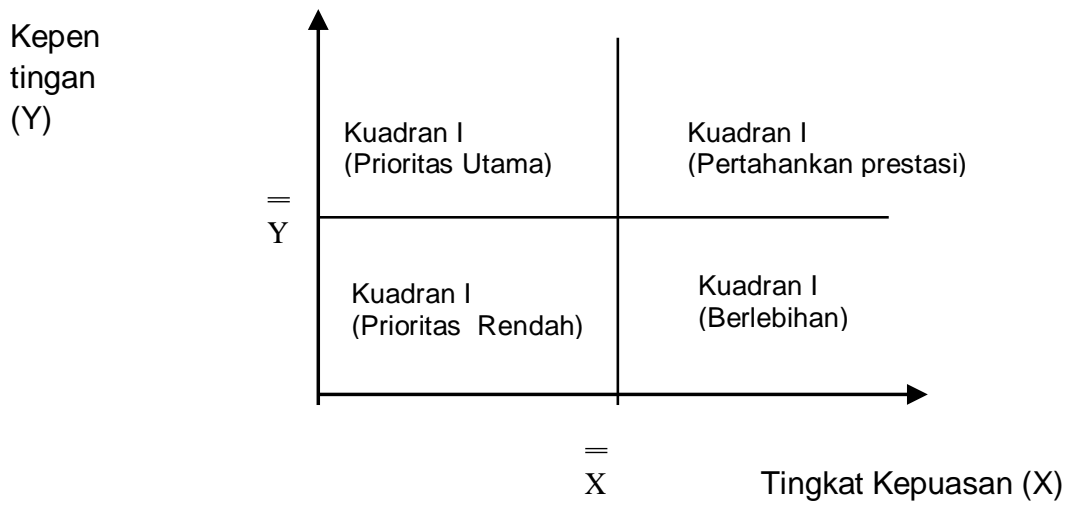

Gambar 1. Diagram Important\&Performance Analysis

\section{HASIL DAN PEMBAHASAN}

\section{Karakteristik Responden}

Kesejahteraan penduduk dapat dilihat dari data komposisi penduduk berdasarkan status kesejahteraan keluarga yang disusun oleh BKKBN menunjukkan tingkat kesejahteraan penduduk di Kelurahan Mulyorejo cukup beragam. Jumlah penduduk di Kelurahan Mulyorejo sebanyak 16.390 jiwa yang terdiri dari 4.199 kepala keluarga, 8.136 orang laki-laki dan 8.254 orang perempuan. Pertumbuhan penduduk tahun 2008 sekitar 1,92 persen per tahun. Usia penduduk beragam dari yang baru lahir sampai di atas 58 tahun. Kelurahan Mulyorejo terdiri dari 12 RW. RW 1 - 4, disebut Perkampungan Lama, dimana sebagian besar penduduknya merupakan Keluarga Pra Sejahtera dan Keluarga Sejahtera I (KS I). KS II dan KS III sebagian besar bertempat tinggal di RW 5 - 8. Daerah ini terletak di Perumahan Wisma Permai dan sekitarnya. Sedangkan pada RW $9-12$, sebagian besar lahannya merupakan perumahan elit yang berada di daerah Dharma Husada yang hampir seluruh penduduknya merupakan KS III plus.

Usia responden berkisar antara 20 - 79 tahun. Responden terbanyak adalah konsumen berusia 40 - 49 tahun. Ini merupakan usia yang matang dalam pengambilan keputusan tentang beras yang dikonsumsi. Suku Jawa merupakan suku yang mendominasi penelitian ini (52\%).

Hampir seluruh responden berjenis kelamin perempuan (97\%) dan berstatus sudah menikah (95\%), karena pengambilan keputusan mengenai konsumsi beras sampai saat ini masih didominasi oleh perempuan. Dapat dikatakan bahwa sebagian besar pengambil keputusan pembelian beras dilakukan oleh perempuan yang telah menikah. 
Jumlah penghuni rumah tangga sebagian besar berjumlah $4-6$ orang $(67 \%)$. Kelas atas cenderung memiliki lebih banyak penghuni rumah karena ada pembantu. Jumlah penghuni rumah akan berpengaruh pada jumlah beras yang dibeli setiap bulan.

Tingkat pendidikan terakhir responden terbanyak adalah SMU (31\%) pada kelas menengah, S1 (26\%) pada kelas atas, dan SD (15\%) pada kelas bawah. Semakin tinggi kelas sosial, maka semakin tinggi pula pendidikannya. Tingkat pendidikan ini menyebabkan semakin peka terhadap informasi dalam proses keputusan pembelian beras.

Sebagian besar responden adalah ibu rumah tangga (40\%). Alasan menjadi ibu rumah tangga bagi responden kelas bawah adalah tidak punya pendidikan yang cukup, sehingga tidak ada alternatif bekerja lainnya selain ibu rumah tangga. Berbeda dengan responden kelas atas, alasan responden kelas atas yang tidak bekerja adalah pendapatan keluarga telah cukup, dan alasan lainnya seperti tidak diperbolehkan bekerja oleh suami sehingga bisa lebih konsentrasi melakukan kewajiban sebagai ibu rumah tangga.

\section{Proses Keputusan Pembelian Beras}

Proses keputusan pembelian beras yang dikaji terdiri dari lima tahap yaitu pengenalan kebutuhan, pencarian informasi, evaluasi alternatif, pembelian dan pasca pembelian yang secara rinci dapat dilihat sebagai berikut :

\section{Pengenalan Kebutuhan}

Keputusan membeli suatu produk diawali ketika konsumen menyadari adanya kebutuhan akan produk tersebut. Kebutuhan akan beras dimotivasi oleh dua manfaat yaitu manfaat utilitarian dan manfaat hedonis. Sebagian besar responden (dari 3 kelas) mengkonsumsi beras dengan memperhatikan manfaat hedonis, yaitu karena sudah kebiasaan (58\%). Itu adalah budaya Indonesia yang terbiasa mengkonsumsi nasi untuk memenuhi kebutuhan karbohidrat.

Frekuensi mengkonsumsi nasi dalam sehari paling banyak adalah tiga kali pada seluruh kelas. Ini menunjukkan rata-rata konsumsi beras masyarakat Indonesia masih tinggi. Namun semakin tinggi kelas sosial, rata-rata konsumsi per kapitanya semakin menurun.

\section{Pencarian Informasi}

Sumber informasi tentang beras pada seluruh kelas didominasi oleh penjual beras karena sumber informasi lainnya seperti iklan sangat terbatas. Walaupun informasi terbanyak diperoleh dari penjual, namun informasi yang paling dipercaya responden adalah informasi yang berasal dari diri sendiri. Responden lebih percaya pada pengalaman pribadi yang telah masuk ke dalam ingatan mengenai beras apa yang mereka konsumsi setiap hari.

Varietas beras yang paling sering disebutkan oleh responden adalah Pandan wangi. Hal ini dikarenakan varietas beras yang sudah terkenal. Kelas sosial yang berbeda memberikan perbedaan yang nyata pada jumlah varietas beras yang diingat. Kelas atas mengingat lebih banyak varuetas beras dibandingkan kelas sosial dibawahnya karena pembelian beras kelas atas dan menengah memakai kemasan yang tercantum nama varietas beras.

\section{Evaluasi alternatif}

Kepulenan adalah variabel yang paling dipertimbangkan konsumen secara keseluruhan karena sebagian responden adalah suku Jawa yang menyukai nasi yang 
pulen. Namun bila dilihat per kelas, kepulenan termasuk pada peringkat dua pada setiap kelas. Hal ini menunjukkan bahwa kepulenan adalah atribut yang sangat penting bagi responden secara keseluruhan, namun bukan yang paling dominan dalam setiap kelas.

Bagi kelas bawah, yang terpenting adalah harga beras mengingat pendapatan yang mereka peroleh sangat terbatas. Bagi kelas menengah dan kelas atas, variabel yang terpenting adalah penampakan beras. Hal ini dikarenakan tingkat pendapatan dan tingkat pendidikan yang lebih tinggi dibandingkan kelas bawah, sehingga kelas menengah dan kelas atas menuntut adanya kualitas yang baik untuk beras yang dikonsumsi, salah satunya adalah dari penampakan beras secara fisik antara lain bersih, putih, bening, dan utuh (persentase broken rendah).

\section{Pembelian Beras}

Hampir seluruh responden (97\%) menyatakan mengkonsumsi beras dalam negeri. Alasan terbesarnya adalah kemudahan mendapatkan beras dalam negeri. Ada $3 \%$ responden yang mengkonsumsi beras impor merupakan responden kelas atas karena daya beli konsumen kelas atas yang lebih tinggi. Selain itu, sebagian besar responden kelas atas didukung oleh pengetahuan, informasi, gaya hidup, dan pendidikan yang memungkinkan responden sadar akan kualitas beras yang lebih baik. Responden tersebut beralasan beras impor kualitasnya lebih baik dari beras dalam negeri.

Pembelian beras memerlukan keterlibatan yang tinggi sehingga lebih cocok digolongkan pada pembelian yang direncanakan, baik sepenuhnya atau separuhnya terencana. Selain itu, kebutuhan beras merupakan kebutuhan pokok yang sangat penting, sehingga responden akan menyediakan sebagian pendapatannya untuk membeli beras.

Sebagian besar responden yang ditanya mengenai varietas beras yang dikonsumsi menjawab tidak tahu, salah menyebut merek, dan lain-lain. Namun semakin tinggi kelas sosial, varietas beras akan semakin mempengaruhi pembelian beras. Ini dikarenakan tingginya pendidikan yang berkorelasi dengan pengetahuan dan gaya hidup kelas atas menyebabkan beras yang dikonsumsi berada harus bersih dalam kemasan yang mencantumkan varietas beras.

Frekuensi pembelian beras bervariasi antar kelas sosial. Kelas sosial yang tinggi memiliki frekuensi pembelian yang sedikit namun dalam jumlah yang besar. Bagi kelas bawah, sebagian besar membeli beras setiap 2-6 hari. Ini dikarenakan pendapatan kelas bawah yang rendah dan tidak menentu. Sedangkan bagi kelas sosial lainnya, pendapatan yang stabil dan alasan kepraktisan menjadi mendorong mereka membeli beras dengan frekuensi rendah dalam jumlah besar.

Keputusan responden dalam menentukan tempat pembelian berbeda antar kelas sosial. Kelas bawah paling sering membeli beras di warung, kelas menengah di pasar tradisional, dan kelas atas di mall/supermarket. Warung merupakan tempat pembelian terbanyak bagi kelas bawah karena merupakan tempat pembelian yang mudah dan tidak mengeluarkan ongkos. Alasan lainnya adalah karena di warung biasanya konsumen boleh membeli dengan cara mengutang. Kelas atas dan menengah memilih tempat pembelian yang tersedia banyak pilihan, pelayanan baik, dan kualitas yang terjamin. Pertimbangan utama dalam menentukan tempat pembelian beras bagi kelas bawah dan menengah adalah lokasi yang mudah dijangkau. Bagi kelas atas, pertimbangan palimg penting adalah kualitas beras yang ada di tempat tersebut.

Pengambil keputusan tentang beras yang dominan adalah istri. Terdapat beberapa suami sebagai pengambil keputusan karena istri yang bekerja. Suami-suami tersebut juga biasanya menjadi pengambil keputusan dalam pekerjaan rumah tangga lainnya. Apabila beras yang diinginkan tidak ada, konsumen akan mencari baras yang 
sama ke tempat lain. Jawaban sama untuk kelas menengah dan atas karena dibanding pertimbangan lainnya, kualitas beras yang mereka konsumsi sangatlah penting. Bagi kelas bawah, bila hal yang sama terjadi, mereka tetap membeli beras lain di tempat tersebut karena telah berlangganan dan boleh berhutang.

\section{Pasca Pembelian}

Sebagian besar responden mempunyai keluhan pasca pembelian beras. Keluhan terbanyak terbanyak dari responden kelas bawah antara lain harga mahal, lalu kurang bersih seperti terdapat kerikil dan gabah, beras tercampur dengan beras lain, apek dan berat netto tidak sesuai ukuran. Keluhan lain broken, tidak tahan lama, pera, ketersediaan tidak kontinyu, dan pelayanan yang kurang memuaskan. Respon terbanyak yang dilakukan konsumen kelas bawah menyampaikan keluhan tersebut pada penjual dan tetap membeli beras dengan jenis yang sama di tempat yang sama dan tidak melakukan apa-apa.

Apabila harga beras dinaikkan, tidak ada responden yang menjawab akan mengganti dengan pangan lain. Sebagian besar menjawab tidak terpengaruh dan akan terus mengkonsumsi beras yang sama. Ini menandakan budaya memakan nasi yang sudah sangat melekat. Semakin tinggi kelas sosial seseorang, maka semakin tidak terpangaruh pada perubahan harga beras.

\section{Analisis Kepuasan}

Tingkat kepuasan dari responden terhadap atribut-atribut beras dalam peneliatian ini dihitung dengan customer satisfaction index (CSI). Hasil perhitungan CSI dapat dilihat pada Tabel 1. CSI untuk ketiga kelas sosial berkisar antara 67,89-77,05\%. Masingmasing CSI berdasarkan kelas sosial yaitu kelas atas $77,05 \%$, kelas menengah $67,87 \%$ dan kelas bawah $67,86 \%$. Nilai CSI pada semua kelas sosial berada pada range $60 \%<$ $\mathrm{CSI} \leq 80 \%$, berarti konsumen pada ketiga kelas tersebut termasuk dalam kategori "puas".

Tabel 1. CSI terhadap atribut beras berdasarkan kelas social di Kecamatan Mulyorejo tahun 2007

\begin{tabular}{lc}
\hline \multicolumn{1}{c}{ Konsumen } & CSI (\%) \\
\hline Kelas Atas & 77,05 \\
Kelas Menengah & 67,87 \\
Kelas Bawah & 67,86 \\
\hline
\end{tabular}

Nilai CSI pada ketiga kelas social yang berada di bawah 100 persen menunjukkan adanya atribut-atribut beras yang dianggap belum memuaskan bagi konsumen. Untuk mengetahui atribut apa belum memuaskan, selanjutnya dilakukan analisis tingkat kepentingan dan kinerja atribut (IPA). Hasil yang diperoleh akan dimasukkan pada diagram IPA (diagram Kartesius) yang menentukan posisi atribut berdasarkan tingkat kepentingan dan tingkat kinerjanya.

\section{Analisis Tingkat Kepentingan - Kinerja Atribut}

Important and Performance Matrix diperlukan untuk melihat kedudukan 19 atribut beras yang diperoleh berdasarkan skor tingkat kepentingan dan skor tingkat kinerja berdasarkan 100 responden. Secara umum konsumen yang mengkonsumsi beras memiliki tingkat kepentingan dan penilaian kinerja yang berbeda terhadap atribut-atribut beras antara kelas bawah, menengah, dan atas. Dari pengetahuan tersebut, dapat difokuskan usaha-usaha yang harus dilaksanakan berdasarkan 4 kuadran dalam diagram 
IPA. Matrix IPA untuk ketiga kelas sosial dapat dilihat pada Gambar 2 sampai dengan Gambar 4.

Tabel 2 Hasil Important and Performance Matrix

\begin{tabular}{|c|c|c|c|}
\hline \multicolumn{4}{|c|}{ Hasil IPA Kelas Atas } \\
\hline Kuadran I & Kuadran II & Kuadran III & Kuadran IV \\
\hline \multirow{3}{*}{$\begin{array}{l}\text { 1. Kemudahan } \\
\text { mendapatka } \\
\mathrm{n} \text { beras (S) }\end{array}$} & 1. Kepulenan (A) & 1. Kemasan (I) & 1. Varietas beras $(\mathrm{G})$ \\
\hline & 2. Aroma (B) & 2. Lokasi penjual beras & 2. Keragaman varietas $\mathrm{d}$ \\
\hline & 3. Warna (C) & (M) & tempat pembelian $(\mathrm{N})$ \\
\hline \multirow{5}{*}{$\begin{array}{l}\text { 2. Pelayanan } \\
\text { penjual }(\mathrm{R})\end{array}$} & 4. Kebersihan (D) & 3. Iklan (K) & 3. Keragaman harga di \\
\hline & 5. Broken $(E)$ & 4. Informasi penjual (Q) & tempat pembelian $(\mathrm{O})$ \\
\hline & $\begin{array}{l}\text { 6. Kesaragaman } \\
\text { beras }(F)\end{array}$ & 5. Harga (L) & 4. Merek (J) \\
\hline & 7. Daya tahan beras $(\mathrm{H})$ & & \\
\hline & $\begin{array}{l}\text { 8. Kenyamanan tempat } \\
\text { pembelian }(P)\end{array}$ & & \\
\hline \multicolumn{4}{|c|}{ Hasil IPA Kelas Menengah } \\
\hline Kuadran I & Kuadran II & Kuadran III & Kuadran IV \\
\hline 1 Broken (E) & 1 Kepulenan $(\mathrm{A})$ & \multirow{8}{*}{$\begin{array}{l}\text { 2. Keragaman harga di } \\
\text { tempat pembelian }(\mathrm{O}) \\
\text { 3. Kenyamanan di tempat } \\
\text { pembelian }(\mathrm{P}) \\
\text { 4. Pelayanan penjual }(\mathrm{R})\end{array}$} & \multirow{8}{*}{$\begin{array}{l}\text { 1. Varietas beras }(\mathrm{G}) \\
\text { 2. Kemasan }(\mathrm{I}) \\
\text { 3. Merek }(\mathrm{J}) \\
\text { 4. Keragaman varietas d } \\
\text { tempat pembelian }(\mathrm{N})\end{array}$} \\
\hline \multirow{2}{*}{$\begin{array}{c}2 \text { Keseragam } \\
\text { an butir (F) }\end{array}$} & 2 Aroma (B) & & \\
\hline & 3 Warna (C) & & \\
\hline \multirow{5}{*}{$\begin{array}{l}3 \text { Daya tahan } \\
(\mathrm{H})\end{array}$} & 4 Kebersihan (D) & & \\
\hline & 5 Harga beras $(\mathrm{L})$ & & \\
\hline & 6 Lokasi penjual (M) & & \\
\hline & 7 Informasi penjual (Q) & & \\
\hline & $\begin{array}{ll}8 & \text { Kemudahan } \\
& \text { mendapatkan beras (S) }\end{array}$ & & \\
\hline \multicolumn{4}{|c|}{ Hasil IPA Kelas Bawah } \\
\hline Kuadran I & Kuadran II & Kuadran III & Kuadran IV \\
\hline 1. Aroma (B) & 1 Kepulenan $(\mathrm{A})$ & 1 Keseragaman butir (F) & 1 Daya tahan $(\mathrm{H})$ \\
\hline \multirow{5}{*}{$\begin{array}{l}\text { 2. Kebersihan } \\
\text { (D) } \\
\text { 3. Broken (E) } \\
\text { 4. Harga (L) }\end{array}$} & 2 Warna $(\mathrm{C})$ & 2 Varietas beras $(\mathrm{G})$ & $2 \operatorname{Iklan}(\mathrm{K})$ \\
\hline & 3 Lokasi Penjual (M) & 3 Merek (J) & 3 Keragaman harga di \\
\hline & 4 Informasi Penjual (Q) & 4 Kemasan (I) & tempat pembelian $(\mathrm{O})$ \\
\hline & $\begin{array}{ll}5 & \text { Kemudahan } \\
& \text { mendapatkan beras (S) }\end{array}$ & $\begin{array}{l}5 \text { Kenyamanan di tempat } \\
\text { pembelian }(\mathrm{P})\end{array}$ & $\begin{array}{l}4 \text { Keragaman varietas di } \\
\text { tempat pembelian }(\mathrm{N})\end{array}$ \\
\hline & & $6 \begin{array}{l}\text { Pelayanan di tampat } \\
\text { pembelian }(\mathrm{R})\end{array}$ & \\
\hline
\end{tabular}

Berdasarkan hasil diagram kartesius, atribut-atribut yang termasuk pada setiap kuadran untuk setiap kelas sosial yang berbeda diringkas pada pada Tabel 2. Pada tabel tersebut dapat dilihat perbandingan mengenai tingkat kepentingan dan kinerja konsumen setiap kelas.

Berdasarkan hasil dari proses keputusan pembelian dan Important and Performance Analysis, diketahui bahwa ketidakpuasan konsumen kelas atas sebagian besar dipengaruhi oleh kinerja dua atribut beras yang dianggap penting bagi konsumen kelas atas namun kinerjnaya belum memuaskan, yaitu kemudahan mendapatkan beras dan pelayanan di tempat pembelian beras.

Kelas menengah belum terpuaskan secara maksimal oleh atribut-atribut beras yang selama ini dikonsumsi. Berdasarkan hasil dari proses keputusan pembelian dan Important and Performance Analysis, diketahui bahwa sebagian besar ketidakpuasan konsumen dipengaruhi oleh kinerja tiga atribut beras yang dianggap penting bagi konsumen kelas menengah namun kinerjanya belum memuaskan, yaitu broken, keseragaman butir beras, dan daya tahan beras untuk disimpan. 
Sedangkan bagi kelas bawah, berdasarkan hasil dari proses keputusan pembelian dan Important and Performance Analysis, diketahui bahwa sebagian besar ketidakpuasan konsumen dipengaruhi oleh kinerja empat atribut beras yang dianggap penting bagi konsumen namun kiberjanya belum memuaskan, yaitu aroma nasi saat dimasak, kebersihan beras, broken, dan harga beras.

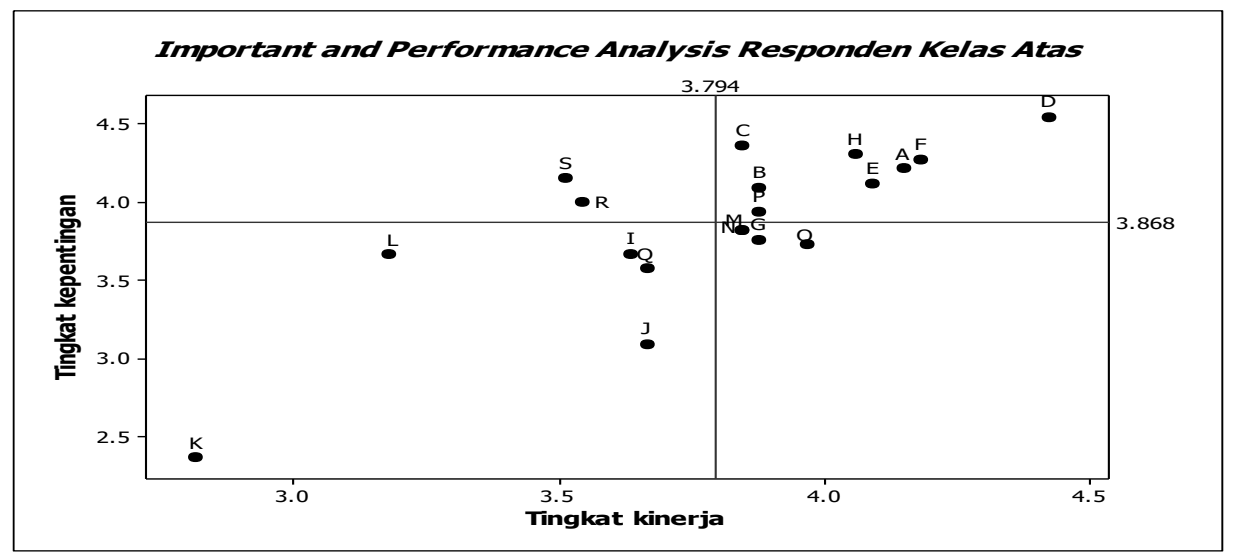

Gambar 2. Tingkat Kepentingan dan Kinerja Atribut Beras Berdasarkan Responden Kelas Atas di Kecamatan Mulyorejo Tahhun 2007.

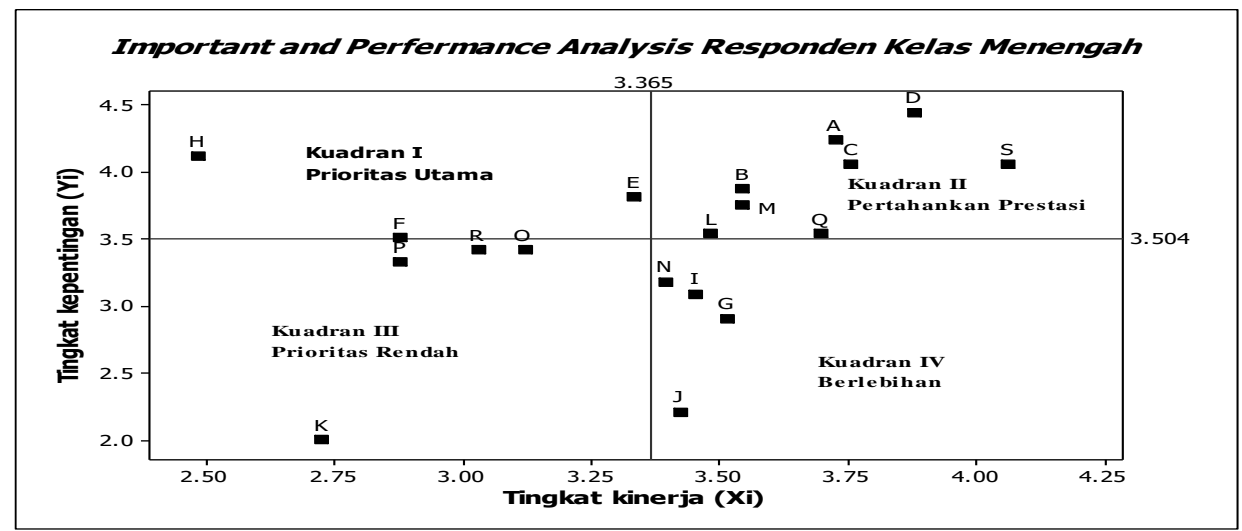

Gambar 3. Tingkat Kepentingan dan Kinerja Atribut Beras Berdasarkan Responden Kelas Menengah di Kecamatan Mulyorejo Tahhun 2007. 


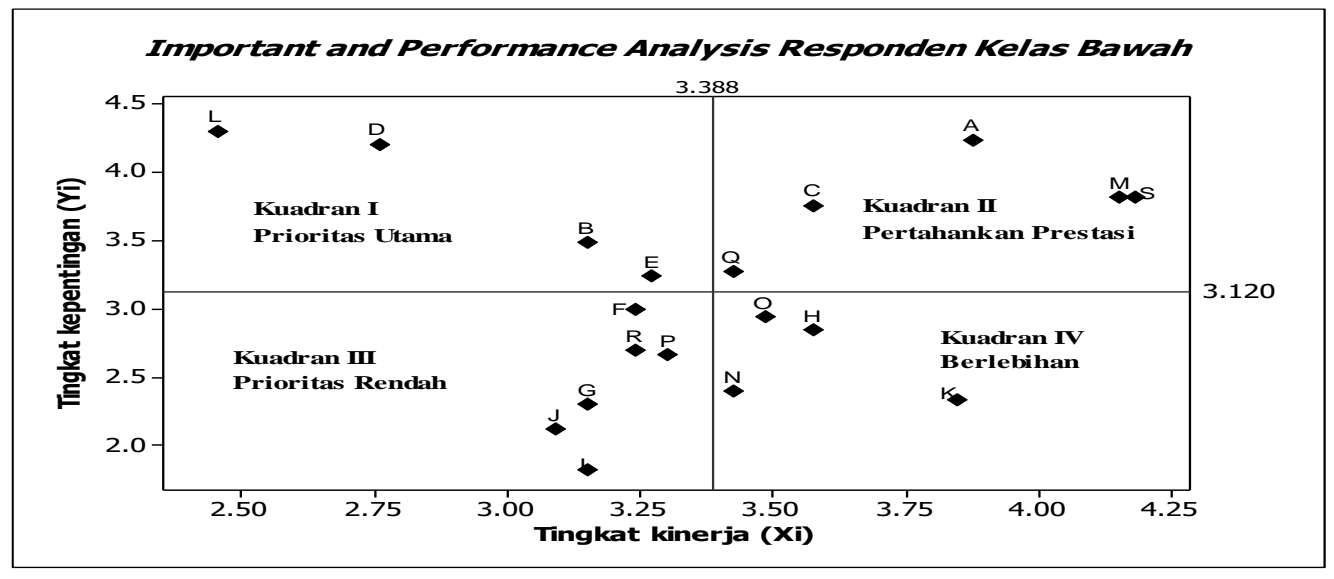

Gambar 4. Tingkat Kepentingan dan Kinerja Atribut Beras Berdasarkan Responden Kelas Bawah di Kecamatan Mulyorejo Tahhun 2007.

\section{SIMPULAN DAN SARAN}

\section{Simpulan}

Terdapat beberapa perbedaan karakteristik konsumen beras berdasarkan kelas sosialnya. Semakin tinggi kelas sosial, tingkat pendidikan dan rata-rata pendapatan per bulan keluarganya akan semakin tinggi. Hal ini mempengaruhi perilaku konsumen dalam mengkonsumsi beras.

Perbedaan dalam proses pengambilan keputusan terdapat pada pertimbangan utama dalam mengkonsumsi beras, frekuensi dan ukuran pembelian, serta tempat membeli beras.

CSI dari ketiga kelas sosial berkisar 67,86 - 77,05 termasuk kategori puas. Atribut yang paling berpengaruh terhadap kepuasan konsumen namun kinerjanya belum memuaskan adalah atribut yang berada pada kuadran I. Semakin tinggi kelas sosial, atribut yang termasuk dalam kuadran ini semakin sedikit. Ini menandakan semakin tinggi kelas sosial, kepuasan yang diperoleh dari beras yang dikonsumsi semakin tinggi. Hal ini terjadi karena beras yang dikonsumsi oleh konsumen dengan kelas sosial yang tinggi adalah beras yang lebih berkualitas dibandingkan dengan yang dikonsumsi oleh konsumen kelas bawah.

\section{Saran}

Berdasarkan proses pengambilan keputusan dan analisis IPA, diketahui bahwa konsumen kelas atas sangat memperhatikan kualitas beras yang dikonsumsi. Sebaiknya untuk konsumen kelas atas didistribusikan beras dengan kualitas yang baik secara kontinyu melalui penjual-penjual yang memperhatikan pelayanan dan kenyamanan tempat penjualan.

Konsumen kelas bawah sangat memperhatikan harga beras dalam proses keputusan pembelian beras dan termasuk atribut yang berada pada kuadran I dalam analisis IPA. Itu artinya konsumen menganggap harga beras sebagai atribut yang penting namun kinerjanya buruk karena dianggap mahal. Untuk konsumen kelas bawah, sebaiknya didistribusikan beras yang lebih terjangkau harganya. 
Pemerintah sebaiknya mendukung terciptanya kualitas beras yang sesuai keinginan konsumen dengan menyediakan input produksi yang bermutu dengan harga terjangkau dan melakukan pendampingan pada petani dalam proses produksi dan pasca panen.

\section{DAFTAR PUSTAKA}

Badan Pusat Statistik. 2005. Data Konsumsi Beras di Indonesia. Jakarta : Badan Pusat Statistik.

Bustaman, A. D. 2003. Analisis Integrasi Pasar Beras di Indonesia. Skripsi. Program Sarjana Ekstensi Manajemen Agribisnis. Fakultas Pertanian. Institut Pertanian Bogor. Bogor.

Jufri. 2006. Analisis Perilaku Konsumen dan Strategi Pemasaran Beras Super Ciherang Lumbung Desa Modern (LDM) Srijaya Kecamatan Tempuran Kabupaten Karawang. Skripsi. Program Sarjana Ekstensi Manajemen Agribisnis. Fakultas Pertanian. Institut Pertanian Bogor. Bogor.

Lipsey, R. G., dkk. 1995. Pengantar Mikroekonomi. Jakarta : Binarupa Aksara.

Nazir, M. 1985. Metode Penelitian. Jakarta : Ghalia Indonesia.

Selamet, R. 2003. Analisis Proses Keputusan Konsumen dalam Penelitian Beras dan Strategi Pemasaran Beras. Skripsi. Program Studi Agribisnis. Jurusan IImu-IImu Sosial Ekonomi Pertanian. Fakultas Pertanian. Institut Pertanian Bogor. Bogor.

Simamora, B. 2004. Panduan Riset Perilaku Konsumen. Jakarta: Gramedia Pustaka Utama.

Stratford. Stratford-on-Avon District Council Customer Satisfaction Index June 2004. httpllwww.stratford.gov.uklcommunitylcouncil-805.cfm.htm. (29 Januari 2007).

Umar H. 2000. Riset Pemasaran dan Perilaku Konsumen. Jakarta: Gramedia Pustaka Utama.

Wirartha, I. M. 2006. Metodologi Penelitian Sosial Ekonomi. Yogyakarta : Andi. 